\title{
РОЛЬ ЛИНКЕРА ФАРМАКОФОРНЫХ ФРАГМЕНТОВ 3-АМИНО-ИЗОХИНОЛИНОВ, ИНГИБИТОРОВ РDЕ4В
}

\author{
Г.Б. Лапа', Н.И. Моисеева² \\ ${ }_{1}^{1}$ РНИМУ им.Пирогова, 117997, Москва, ул. Островитянова 1. \\ РОНЦ им. Блохина, 115478, Москва, Каширское ш. 23.
}

DOI: 10.19163/MedChemRussia2021-2021-523

E-mail: lapa.g@yandex.ru

Фосфодиэстеразы (PDE) интегрированы в мембранные сигналосомы, гидролизуют циклические нуклеотиды (сAMP, cGMP) и регулируют их концентрации в разных отделах клетки. ${ }^{1}$ Изоформы PDE4 гиперэкспрессированы в некоторых опухолей крови и ЖКT, в KRAS сигнальных путях, нарушающих регуляцию клеточного цикла. ${ }^{1}$ Ранее мы установили, что 3-амино-изохинолины являются селективными ингибиторами PDE4B (h. sapiens) и тормозят рост чувствительных человеческих опухолевых клеточных линий: HCT116, HKe3-mtKRAS, K562, T-47D с IC50 в диапазоне 10-1 $\mu$ M. $^{2}$ Мы уже показали, что 1-метил-3-амино-6,7-диметоксиизохинолин (фрагмент A) и пара-замещенный арил (фрагмент В) являются важными частями фармакофора ингибиторов (h. sapiens) PDE4B. ${ }^{3}$

Фармакофор определяли с помощью LigandScout_4.0 докинга 3-N-замещенных-1-метилизохинолинов в активный центр PDE4B (1xm4.pdb) (по протоколу Vina). Дополнительно, фармакофор создавали в PharmaGist на основе выровненных структур пикламиласта, рофлумиласта и цикломиласта. Мы обнаружили, что оба фрагмента фармакофора для человеческой PDE4B, соединенных «длинными» и/или объемными линкерами, проявляют меньшую активность, чем эти же фрагменты, соединенные коротким, одноуглеродным фрагментом. LGB-047 $\left(\mathrm{X}=-\mathrm{CH}_{2}^{-}\right.$) показало умеренную активность на клеточных линиях $\mathrm{HCT116} \mathrm{с} \mathrm{IC} 1.9$ $\mu \mathrm{M}$ и К562 с IC 50 $9.6 \mu \mathrm{M}$.

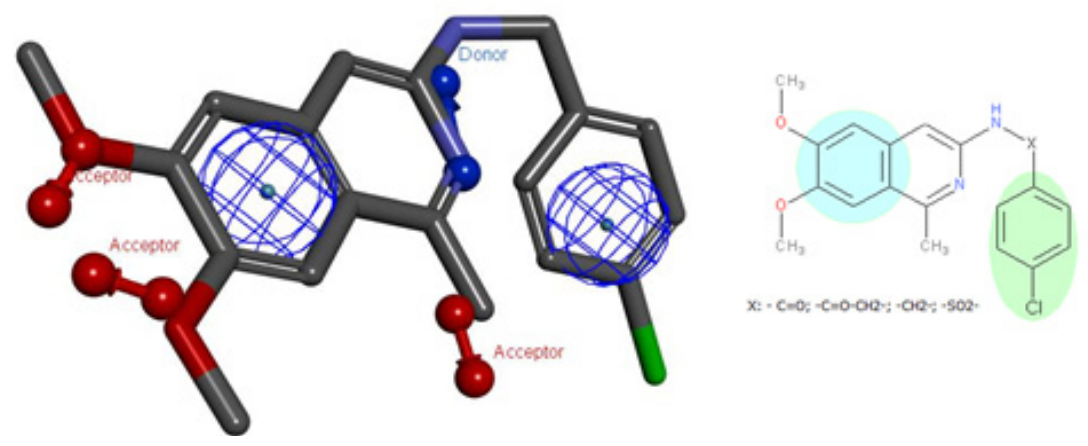

\section{Литература}

1. Padda IS, Tripp J. Phosphodiesterase Inhibitors. StatPearls Publishing; 2021 Jan.

2. Lapa, G.B.; Tsunoda, T.; et al. Chem Biol Drug Des. 2016. 87: 575-582.

3. Лапа Г.Б., Моисеева Н.И. Росс. Биотерапевт. Ж, 2016, 15, № 1, с. 57. 